\title{
Gut
}

Leading article

\section{Mycobacterial diseases of the gut: some impact from molecular biology}

At present Crohn's disease is by far the most important unresolved intestinal problem with a presumptive mycobacterial association. When the progress of Crohn's disease research throughout the 20th century is reviewed from the vantage of the 21st, some familiar patterns will be recognised. From its earliest definitive descriptions, ${ }^{12}$ Crohn's disease was suspected of having a mycobacterial cause, but with the failure of the available techniques of microscopy and culture to show specific pathogens, the likelihood of mycobacterial involvement was difficult to sustain and understandably fell into abeyance. Little real advance occurred for almost 50 years. Concepts of aetiology have meandered between those that invoked cornflakes, toothpaste, or a more general food allergy on the one hand, and the more scientifically respectable possibilities of viruses and autoimmunity on the other.

From the late 1970s a new era began with renewed attempts at mycobacterial culture, to grow specific pathogens from Crohn's disease and other tissues. ${ }^{3-6}$ About 10 years' persistent work by a small number of research groups showed that bacillary mycobacteria could be cultured from the tissues of about one in five cases of both Crohn's disease and ulcerative colitis, and from the tissues of about one in 10 noninflammatory bowel disease controls. The figures for spheroplasts, whose nature was often unknown, were about two in five for Crohn's disease, one in five for ulcerative colitis, and rarely from non inflammatory bowel disease controls. ${ }^{78}$ Where bacillary isolates could be identified, the range of mycobacterial strains corresponded broadly with those that could be cultured from a majority of normal human faeces. ${ }^{9}$ The relation between mycobacteria, Crohn's disease, and ulcerative colitis was properly summarised as uncertain..$^{10}$ Progress depended on the development and application of new technology.

By 1984-5, and after considerable preparatory work, the techniques of molecular biology had been taken up by some laboratories working in the field of intestinal diseases in both veterinary and human medicine, and started to have an impact on Crohn's disease. The 10 year period since the work of Boyer and Cohen (and many others) had seen a massive advance in understanding and technical capability in molecular biology, and with this also came the expanding commercial availability of increasingly well defined critical reagents. Long term in vitro culture of Crohn's disease intestinal tissue contributed just enough material for the preparation of nanogram quantities of the essential starting DNA. ${ }^{+}$The discovery of the IS 900 family of DNA insertion elements (IS) in environmental mycobacteria beginning with the specific intestinal pathogen Mycobacterium paratuberculosis, ${ }^{112}$ and the advent of the polymerase chain reaction (PCR), ${ }^{13}$ have provided the means of detecting and identifying these organisms directly via their DNA with great precision and sensitivity. ${ }^{1+15}$ This is particularly important because the small group of potentially relevant human pathogens, many of which cannot be isolated with certainty from animals even when known to be the cause of chronic enteritis, ${ }^{16}$ are obscured within much larger groups of often very closely related environmental mycobacteria, from which they are difficult or impossible to distinguish by conventional means.

There is, of course, nothing at all 'magic' about the ISspecific PCR detection system for environmental mycobacteria. However, sample preparation, critical reagents, and reaction conditions, as well as operating procedures which strictly exclude artefact due to laboratory contamination, have to be 'just right'. When they are appropriately designed and applied to tissue DNA extracts, these assays show the previously unsuspected presence of $M$ paratuberculosis in the intestine of a small proportion of seemingly normal people, and in the inflamed intestines of a majority of people with Crohn's disease in southern England. ${ }^{17}$ Our own studies at present show that the proportional presence of $M$ paratuberculosis in ulcerative colitis intestine does not exceed that of non-inflammatory bowel disease controls. Much research needs to be done, particularly by collaborating groups in different countries, before the importance of these early results is certain. The determination of the DNA sequence of IS902 in the 'wood pigeon' strain of $M$ avium ${ }^{18}$ ( $M$ avium subsp silvaticum ${ }^{19}$ ), has permitted the development of the corresponding specific PCR assay. This organism is a known cause of chronic enteritis in some animals ${ }^{20}$ and IS 902 assays will also be useful in determining the relation of its host mycobacterium to human intestinal disease.

Because they are present in multiple copies and seem relatively immobile within the host mycobacterial genome, IS900 and IS902 can also be used to differentiate individual disease isolates of $M$ paratuberculosis and $M$ avium subsp silvaticum by RFLP analysis. ${ }^{1821}$ This may lead to the identification of subtypes of $M$ paratuberculosis and $M$ avium subsp silvaticum with preferred animal and human specificities. The rapid identification of individual species specific pathogens may subsequently become possible using 
PCR assays independent of successful in vitro culture, when the genomic locations and flanking sequences of all the copies of the relevant IS in the corresponding mycobacterium have been mapped and sequence characterised. Although progress in our attempts to understand and overcome Crohn's disease may flow from the use of these methods, the overall approach is applicable experimentally to some of the known intestinal mycobacterioses. It is also applicable to conditions of uncertain aetiology such as minimal colitis, and to research into generalised disorders like sarcoidosis and rheumatoid arthritis.

The ability of DNA based methods to identify specific pathogens directly among widespread environmental mycobacteria is, for the first time, enabling us to identify the prevalence of these agents in milk, food, and water supplies. Improved culture methods will still be necessary to determine whether positive results are due to the presence of live mycobacteria or residual DNA. We may need to be prepared for some disturbing experimental findings whose interpretation will require caution and an understanding of the biology of these organisms. It is possible that these studies might lead to the introduction of public health measures and new operating procedures, for the prevention of diseases caused by pathogenic environmental mycobacteria on a population basis.

Wider understanding of the biology of environmental mycobacteria and their relation with animal and human hosts is needed. The Table lists most of the known mycobacteria.

The known mycobacteria have been arranged into the much larger group of environmental mycobacteria and the small group of obligate pathogens. The environmental mycobacteria comprise opportunistic pathogens and those that rarely, if ever, cause disease in humans and animals. The main body of environmental mycobacteria have survived on the planet, probably since Gondwana was a cluster of land masses at the South Pole. They have become a robust and versatile species which mostly live 'out there', in soil and on the surfaces of plants, in water, in dust and in the sea. ${ }^{22}$ Some are now inhabitants of the contemporary animal and human intestine. Their long familiarity with our own more complex eukaryotic cells throughout evolution and their independence of them for survival, sustains a generally benign relationship in which the natural balance between an acquiescent cohabitation and a hostility of low intensity is delicately poised, unless of course we are particularly enfeebled. The small group of obligate pathogens, on the other hand, can be viewed as former members of the main environmental body which lost their streetwise ability to survive and prosper 'out there', and segregated to become dependent on the much more regulated hothouse climate of animal and human bodies. Their relationship with us became malignant and

\begin{tabular}{lll} 
Known mycobacteria & & \\
\hline Environmental mycobacteria & & \\
\hline Generally non-pathogenic & Potentially pathogenic & Obligate pathogens \\
\hline M gordonae & $M$ avium & M tuberculosis \\
$M$ gastri & $M$ intracellulare & $M$ bovis \\
$M$ asiaticum & $M$ kansasii & $M$ africanum \\
$M$ terrae & $M$ xenopi & $M$ leprae \\
$M$ triviale & $M$ farcinogenes & M lepraemurium \\
$M$ nonchromogenicum & $M$ fortuitum & \\
$M$ flavescens & $M$ chelonae & \\
$M$ thermoresistibile & $M$ scrofulaceum & \\
$M$ smegmatis & $M$ marinum & \\
$M$ vaccae & $M$ ulcerans & \\
$M$ phlei & $M$ malmoense & \\
$M$ parafortuitum & $M$ szulgai & \\
$M$ aurum & $M$ haemophilum & \\
$M$ gilvum & $M$ simiae & \\
$M$ duvalii & $M$ microti & \\
$M$ chitae & $M$ paratuberculosis & \\
$M$ gadium & $M$ senegalense & \\
$M$ neoaurum & \\
$M$ komossense & \\
\hline
\end{tabular}

their survival dependent on their ability to spread directly from the weak and infected, to a new host.

These are not irrelevant considerations, but can be a direct guide to our research into prevention and treatment. The environmental mycobacteria, including potential intestinal pathogens, are manifestly able to survive the temperate range of climatic heat and cold, light and dark, wet and dry. The pigment of some chromogens may protect them from ultraviolet irradiation. These are the robust organisms whose inactivation in milk by Pasteurisation we currently assume, in part because their now distant hothouse relatives like $M$ tuberculosis and $M$ bovis are known to succumb. The techniques of molecular biology are permitting us to take a new look at this assumption. Likewise, the environmental mycobacteria have been living 'out there' successfully with other soil and water organisms for millions of years. These all coexist in a chaos where the flux of competitive advantage and disadvantage is influenced by products and mechanisms of specific offense and defense. These include antibiotics and the enzymes and metabolic by-passes which destroy or discount them. Only a fraction of these are recognised, but if environmental $M$ avium or $M$ paratuberculosis bacilli, for example, were to die whenever they encountered streptomyces weapons like rifampicin, streptomycin, or kanamycin, they would not be here now. These products, however, kill hothouse ancestral segregants like $M$ tuberculosis which have 'forgotten' their environment smart skills.

We need to progress from a static bewilderment which asks how intestinal conditions like Crohn's disease can have a mycobacterial cause when our contemporary range of antimycobacterial drugs are not often lastingly effective? To our knowledge the relation between $M$ paratuberculosis and human cells in culture has never been systematically researched. We need to exploit transfection assays to identify genes in $M$ paratuberculosis and related pathogens which encode pathogenicity determinants such as those involved in cell penetration and intracellular survival. These studies may permit the development of improved vaccines for animals as well as for humans at special risk.

Some early therapeutic benefit for Crohn's disease may come fortuitously as a result of current efforts within the pharmaceutical industry to find better treatments for mycobacterial superinfections in AIDS patients. Beyond this, the purposeful development of new drugs for the treatment of Crohn's disease is a dauntin ${ }_{c}^{-}$prospect. New compounds will need to penetrate parasitised host cells and will probably not be unmodified natural products of other soil organisms. Drugs which attack cell wall synthesis will not be of use because the relevant intracellular mycobacteria are in spheroplast form anyway. Compounds designed to act during mycobacterial division may encounter organisms that divide only once every few weeks. A more detailed understanding of the biochemistry of the intracellular parasite-host cell relationship is obviously needed.

There are about 18 copies of the IS900 gene in $M$ paratuberculosis and they seem to be transcriptionally active. They encode a protein of $43 \mathrm{kDa} .{ }^{12}$ IS 902 in $M$ avium subsp silvaticum predicts a similar protein of $44 \mathrm{kDa} .^{18}$ Search of available sequence databases as yet shows no homologies that suggest a function. The products of IS900 and IS902 together with the related proteins from IS 110 in Streptomyces coelicolor $^{23}$ and IS116 in $S$ clavuligerus $^{2+}$ all have a conserved motif DAKDA in the amino terminal half of these molecules. This aligns with a conserved sequence required for activity in retroviral and other reverse transcriptases. ${ }^{25}{ }^{26}$ Although the mycobacterial proteins do not have YXDD also found to date in reverse transcriptases, the possibility remains that they are an unusual mycobacterial form of this enzyme. Rifabutin (ansamycin; LM427), a manmade modification of natural rifampicin, is more potent than the parent molecule against 
$M$ paratuberculosis in vitro. Rifabutin also inhibits HIV-1 and inhibits markedly its reverse transcriptase. ${ }^{27}$ It may be the case, that enhanced action of Rifabutin against $M$ paratuberculosis is not because of an improved action against its conventional RNA polymerase target, but because it inhibits putative mycobacterial reverse transcriptase. If this were so, the recombinant $43 \mathrm{kDa}$ product of IS 900 would be a promising candidate for structural studies and computer modelling, leading to the rational design of more effective chemotherapeutic agents against these organisms. ${ }^{28}$

J D SANDERSON J HERMON-TAYLOR

Department of Surgery,
St George's Hospital Medical School,

Blackshaw Road

Blackshaw Road
London SW 17

Correspondence to: Professor J Hermon-Taylor

1 Dalziel TK. Chronic interstitial enteritis. BMF 1913; ii: 1068-70.

2 Crohn BB, Ginzburg L, Oppenheimer GD. Regional ileitis, a pathologic and clinical entity. FAMA 1932; 99: 1323-9.

3 Burnham WR, Lennard-Jones JE, Stanford JL, Bird RG. Mycobacteria as a possible cause of inflammatory bowel disease Lancet 1978; ii: 693-6.

4 Chiodini RJ, van Kruiningen HJ, Merkal RS, Thayer WR, Coutu JA. Characteristics of an unclassified mycobacterium species isolated from Characteristics of an unclassified mycobacterium species iso
patients with Crohn's disease. $\mathcal{F}$ Clin Microbiol 1984; 20: 966-71.

patients with Crohn's disease. F Clin Microbiol 1984; 20: 966-71.
5 Markesich DC, Graham DY, Yoshimura HH. Progress in culture and subculture of spheroplasts and fastidious acid-fast bacilli isolated from intestinal tissues. F Clin Microbiol 1988; 26: 1600-3.

6 Haagsma J, Mulder CJJ, Eger A, Bruins J, Ketel RJ, Tytgat GNJ. Mycobacterium species isolated from patients with Crohn's disease. In: MacDermott RP (ed). Inflammatory bowel disease: current status and future approach. Amsterdam: Excerpta Medica, 1989; 535-7.

7 Chiodini RJ. Crohn's disease and the mycobacterioses: a review and comparison of two disease entities. Clin Microbiol Rev 1989; 2: 90-117.

8 Hermon-Taylor J, Moss M, Tizard MLV, Malik Z, Sanderson J. Molecular biology of Crohn's disease mycobacteria. In: Ciclitira PJ (ed) Baillere Clinical Gastroenterology 1990; 4: 23-42.

9 Portaels F, Larsson L, Smeets P. Isolation of mycobacteria from healthy persons' stools. Int $\mathcal{F}$ Lepr Other Microbact Dis 1988; 56: 468-71.

10 Graham DY, Markesich DC, Yoshimura HH. Mycobacteria and inflammatory bowel disease. Gastroenterology 1987; 92: 436-42.

11 McFadden JJ, Butcher PD, Chiodini R, Hermon-Taylor J. Crohn's diseaseisolated mycobacteria are identical to Mycobacterium paratuberculosis as determined by DNA probes that distinguish between mycobacterial species. f Clin Microbiol 1987; 25; 796-801.
12 Green EP, Tizard MLV, Moss MT et al. Sequence and characteristics of IS900, an insertion element identified in a human Crohn's disease isolate of Mycobacterium paratuberculosis. Nucl Acid Res 1989; 17: 9063-73.

13 Saiki RK, Scharf S, Faloona F, et al. Enzymatic amplification of (3-globulin genomic sequences and restriction site analysis for diagnosis of sickle cell genomic sequences and restriction
anaemia. Science $1985 ; 230$ : 1350-4.

14 Vary PH, Andersen PR, Green E, Hermon-Taylor J, McFadden JJ. Use of highly specific DNA probes and the polymerase chain reaction to detect Mycobacterium paratuberculosis in Johne's disease. F Clin Microbiol 1990; 28: 933-7.

15 Moss MR, Green EP, Tizard MLV, Malik ZP, Hermon-Taylor J. Specific detection of Mycobacterium paratuberculosis by DNA hybridisation with a fragment of the insertion element IS900. Gut 1991; 32: 395-8.

16 Chiodini RJ, van Kruiningen HJ, Merkal RS. Ruminant paratuberculosis (Johne's disease): the current status and future prospects. Cornell Vet 1984; 74: $218-62$.

17 Sanderson JD, Malik Z, Moss MT, Tizard MV, Green EP, Hermon-Taylor J. Polymerase chain reaction (PCR) directly reports Mycobacterium paratuberculosis genomes in Crohn's disease tissue DNA extracts. Gastroenterology 1991; 100: A247.

18 Moss MT, Malik Z, Tizard MLV, Green EP, Sanderson JD, Hermon-Taylor J. IS 902 , an insertion element of the chronic enteritis causing Mycobacterium J. IS902, an insertion element of the chronic enteritis causir

19 Thorel M-F, Krichevsky M, Levy-Frebault VV. Numerical taxonomy of mycobactin-dependent mycobacteria, emended description of Mycobacterium avium, and description of Mycobacterium avium subsp. avium subsp. nov., Mycobacterium avium subsp. paratuberculosis subsp. nov., and Mycobacterium avium subsp., silvaticum subsp. nov. Int $\mathcal{F}$ Systematic Bacteriology 1990; 40: 254-60.

20 Matthews PRJ, McDiarmid A. The production in bovine calves of a disease resembling paratuberculosis with a Mycobacterium sp. isolated from a woodpigeon (Columbia palumbus L). Vet Rec 1979; 104: 286.

21 Whipple D, Kapke P, Vary C. Identification of restriction fragment length polymorphisms in DNA from Mycobacterium paratuberculosis. $\mathcal{F}$ Clin Microbiol 1990; 28: 2561-4.

22 Kazda JF. The principles of the ecology of mycobacteria. In: Ratledge C, Stanford J (eds). The biology of the mycobacteria (vol 2) London: Academic Stanford J (eds). The t

23 Bruton CJ, Chater KF. Nucleotide sequence of IS110, an insertion sequence of Streptomyces coelicolor A3 (2). Nuc Acid Res 1987; 15: 70533-7065.

24 Leskiw BK, Mevarech M, Barritt LS, et al. Discovery of an insertion sequence, IS116, from Streptomyces clavuligerus and its relatedness to other transposable elements from actinomycetes. F Gen Microbiol 1990; 136: $1251-8$.

25 Johnson MS, McClure MA, Feng D-F, Gray F, Doolittle RF. Computer analysis of retroviral pol genes: assignment of enzymatic functions to specific sequences and homologies with nonviral enzymes. Proc Natl Acad Sci 1986; 83: 7648-52.

26 Xiong Y, Eickbush TH. Origin and evolution of retroelements based upon their reverse transcriptase sequences. $E M B O \mathcal{F} 1990 ; 9: 3353-62$.

27 Anand R, Moore JL, Curran JW, Srinivasan A Interaction between rifabutin and human immunodeficiency virus type 1 : inhibition of replication and human immunodeficiency virus type 1: inhibition of replication cytopathic effect and revers

28 Hermon-Taylor J. Mycobacterium paratuberculosis, environmental mycobacteria, and Crohn's Disease. In: Peters TJ (ed). The cell biology of inflammation in the gastro-intestinal tract. Hull: Corners Publications, 1990, $323-42$. 